\title{
ANALISIS FAKTOR RISIKO PERILAKU MEROKOK PADA USIA REMAJA: LITERATUR REVIEW
}

\section{Uswatun Hasanah, Zahratul Hayati}

Fakultas Kesehatan Masyarakat, Universitas Airlangga Surabaya, Indonesia

Email: uswatunhasanahgafar97@gmail.com, zahratulhayati.fkmuh@gmail.com

\begin{abstract}
Abstrak
Merokok merupakan salah satu permasalahan kesehatan yang sering terjadi di Indonesia serta menjadi salah satu faktor utama dari munculnya berbagai macam penyakit hingga menyebabkan kematian. WHO memperkirakan jumlah perokok yang tersebar di Indonesia sampai tahun 2025 yakni meningkat hingga mencapai 90 juta orang bahkan $45 \%$ dari jumlah populasi menganggap bahwa rokok merupakan suatu kebutuhan. Penelitian ini bertujuan untuk memberikan informasi terkait faktor risiko perilaku merokok pada usai remaja berdasarkan kajian review (literature review). Penelitian ini menggunakan metode deskriptif dengan pendekatan literature review. Penelitian ini juga menggunkaan penelitian-penelitian terdahulu dengan kriteria terindeks Sinta 2, 3, 4 dan 5 serta waktu publikasi maksimal 5 tahun terakhir. Faktor risiko yang dapat mempengaruhi seorang remaja melakukan perilaku merokok yakni pengetahuan tentang rokok sehingga dapat mempengaruhi sikap remaja dalam menentukan sikap, kemudian peran orang tua dalam mengomunikasikan bahaya terkait rokok, pengaruh teman sebaya saat berkumpul, pengaruh iklan yang disiarkan di televisi maupun sosial media, uang saku yang diberikan pada sang anak serta adanya rasa ingin tahu atau coba-coba dalam mengonsumsi rokok. Merokok merupakan salah satu pemicu munculnya berbagai macam jenis penyakit hingga menyebabkan kematian, maka diperlukan sosialisasi terkait bahaya merokok pada kalangan remaja sehingga terhindar dari berbagai macam faktor pemicu timbulnya rasa ingin tahu untuk mengonsumsi rokok.
\end{abstract}

Kata Kunci: faktor risiko; perilaku; merokok; usia remaja; literatul review

\section{Abstract}

Smoking is one of the health problems that often occur in Indonesia and is one of the main factors from the emergence of various diseases to cause death. WHO estimates the number of smokers spread in Indonesia until 2025, which increases to reach 90 million people and even $45 \%$ of the population considers cigarettes a necessity. This study aims to provide information related to risk factors for smoking behavior in adolescents based on a review (literature review). This research uses descriptive methods with a literature review approach. This study also uses previous studies with indexed criteria Sinta 2, 3, 4 and 5 and the maximum publication time of the last 5 years. Risk factors that can affect a teenager's smoking behavior are knowledge of cigarettes so that it can affect the attitude of

$\begin{array}{ll}\text { How to cite: } & \text { Hasanah. U \& Zahratul Hayati (2022) Analisis Faktor Risiko Perilaku Merokok Pada Usia Remaja: } \\ & \text { Literatur Review. Syntax Literate: Jurnal Ilmiah Indonesia, 7(1). http://dx.doi.org/10.36418/ Syntax- } \\ & \text { Literate.v7i1.6029 } \\ \text { E-ISSN: } & 2548-1398 \\ \text { Published by: } & \text { Ridwan Institute }\end{array}$


adolescents in determining attitudes, then the role of parents in communicating the dangers related to cigarettes, the influence of peers when gathering, the influence of advertisements broadcast on television and social media, pocket money given to the child and the curiosity or trial and error in consuming cigarettes. Smoking is one of the triggers for the emergence of various types of diseases to cause death, so socialization is needed related to the dangers of smoking in adolescents so as to avoid various factors triggering the emergence of curiosity to consume cigarettes.

Keywords: risk factors; behavior; smoking; teenage years; literatul review

Received: 2021-12-20; Accepted: 2022-01-05; Published: 2022-01-15

\section{Pendahuluan}

Remaja berasal dari bahasa latin yakni "adolensence" yang artinya tumbuh atau tumbuh menjadi lebih dewasa. Istilah ini memiliki arti yang luas dimana mencakup kematangan mental, emosional sosial dan fisik seseorang. Masa remaja merupakan masa peralihan dari masa kanak-kanak ke masa dewasa hal ini ditunjukkan dengan berbagai perubahan meliputi perubahan biologis, perubahan psikologis dan perubahan sosial. Perubahan tersebut mempengaruhi perilaku remaja dalam lingkungan masyarakat. Perubahan perilaku remaja ini meliputi perubahan ke arah positif dan ada juga yang ke arah negatif. Salah satu perilaku negatif yang sering terlihat pada remaja adalah remaja dengan perilaku merokok (Bukit, 2019).

Indonesia menduduki ranking satu dengan jumlah perokok tertinggi di dunia. Jumlah perokok di Indonesia tahun 2016 mencapai 90 juta jiwa. Indonesia sendiri menempati urutan tertinggi prevalensi merokok bagi laki-laki di ASEAN yakni sebesar 67,4\%. Kenyataan ini diperparah bahwa perokok di Indonesia usianya semakin muda. Data Komisi Nasional Perlindungan Anak menunjukkan jumlah perokok anak di bawah 10 tahun di Indonesia mencapai 239.000 orang, 19,8\% pertama kali mencoba rokok sebelum usia 10 tahun, dan hampir 88,6\% pertama kali mencobanya di bawah 13 tahun. Prevalensi merokok di Indonesia sangat tinggi di berbagai lapisan masyarakat, terutama pada laki-laki mulai dari anak-anak, remaja dan dewasa. Kecenderungan merokok terus meningkat dari tahun ke tahun pada lakilaki dan perempuan. Hampir $80 \%$ perokok mulai merokok ketika usianya belum mencapai 19 tahun. Umumnya orang mulai merokok sejak muda dan tidak tahu risiko mengenai bahaya adiktif rokok. Keputusan konsumen untuk membeli rokok tidak didasarkan pada informasi yang cukup tentang risiko produk yang dibeli, efek ketagaihan dan dampak pembelian yang dibebankan pada orang lain (Rezeki \& Utari, 2021).

Merokok merupakan salah satu perilaku yang berbahaya bagi kesehatan, namun perilaku ini masih sulit untuk dihilangkan. Tingkat konsumsi rokok di Indonesia justru menunjukkan angka yang relatif lebih tinggi dibandingkan dengan negara-negara lain di Asia tenggara. World Health Organization (WHO) mencatat saat ini 36\% penduduk Indonesia merokok, atau lebih dari 60 juta orang. WHO juga memperkirakan jumlah perokok di Indonesia tahun 2025 akan meningkat menjadi 90 juta orang, atau $45 \%$ dari 
jumlah populasi (Larasati, 2016). Indonesia sebagai negara terbesar ketiga didunia dengan persentase perokok berat terbanyak setelah Cina dan India. Bahkan Indonesia mendapat penghargaan Asthray Award atau negara keranjang nikotin (Astuti, 2018).

Tembakau membunuh lebih dari 7 juta orang setiap tahun. Lebih dari 6 juta kematian tersebut akibat dari penggunaan tembakau langsung dan 890.000 orang akibat terpapar oleh asap rokok (perokok pasif) dan berdasarkan hasil Riskesdas tahun 2018prevalensi merokok 9,1\% yaitu pada penduduk umur 10-18 tahun. Selain itu proporsi konsumsi tembakau pada penduduk Indonesia usia 15 tahun ke atas adalah pria $62,9 \%$ dan wanita 4,8\%. Proporsi Merokok pada Penduduk Umur $\geq 10$ Tahun di Indonesia dengan perilaku merokok setiap hari sebesar $24,3 \%$ dan merokok kadangkadang sebesar $4,6 \%$.

\section{Metode Penelitian}

Penelitian ini menggunakan metode deskriptif dengan pendekatan literature review. Penelitian ini juga menggunkaan penelitian-penelitian terdahulu dengan kriteria terindeks Sinta 2, 3, 4 dan 5 serta waktu publikasi maksimal 5 tahun terakhir. Jumlah artikel yang ditemukan yakni sebanyak 21.600, akan tetapi yang sesuai yakni sebanyak 10 artikel yang diambil sesuai dengan topik yang berkaitan dengan faktor risiko dari perilaku merok di usia remaja. Pada tabel 1 ini memberikan gambaran terkait artielartikel yang digunakan dalam melakukan literature review yang sudah memenuhi kriteria.

\section{Tabel 1}

Artikel yang digunakan dalam literatul review

\begin{tabular}{|c|c|c|c|}
\hline No. & $\begin{array}{c}\text { Nama Penulis, } \\
\text { Tahun Terbit, Judul }\end{array}$ & Penerbit & Temuan dalam penelitian \\
\hline 1 & $\begin{array}{lr}\text { (Bukit, 2019) } & \text { Faktor } \\
\text { Penyebab } & \text { Perilaku } \\
\text { Merokok Di } & \text { SMK } \\
\text { Akbar Kota Pekanbaru }\end{array}$ & $\begin{array}{l}\text { Ensiklopedia } \\
\text { Of Journal }\end{array}$ & $\begin{array}{lr}\text { Terdapat hubungan antara sikap, } \\
\text { pengetahuan dan tindakan terhadap } \\
\text { perilaku merokok yang bisa dipengaruhi } \\
\text { oleh lingkungan sekitar sehingga } \\
\text { responden mencoba-coba } \\
\text { melakukan tindakan merokok. }\end{array}$ \\
\hline 2 & $\begin{array}{l}\text { (Rezeki \& Utari, 2021) } \\
\text { Faktor-Faktor yang } \\
\text { Mempengaruhi } \\
\text { Perilaku Merokok } \\
\text { Pada Anak Sekolah } \\
\text { Dasar di SD Pinggiran } \\
\text { Banda AcehTahun } \\
\text { 2021. }\end{array}$ & $\begin{array}{l}\text { Journal of } \\
\text { Healthcare } \\
\text { Technology } \\
\text { and Medicine }\end{array}$ & $\begin{array}{l}\text { Terdapat hubungan yang signifikan } \\
\text { antara variabel jenis kelamin, teman } \\
\text { sebaya, iklan, peran keluarga merokok, } \\
\text { dan uang saku dengan perilaku. Namun } \\
\text { terdapat faktor yang paling utama } \\
\text { sehingga mempengaruhi responden } \\
\text { dalam mengonsumsi rokok yakni teman } \\
\text { sebaya. }\end{array}$ \\
\hline 3 & $\begin{array}{l}\text { (Astuti, 2018) Perilaku } \\
\text { Merokok Remaja Laki- } \\
\text { laki Siswa SMP } \\
\text { Swasta di Depok }\end{array}$ & ARKESMAS & $\begin{array}{l}\text { Faktor norma subyektif adalah faktor } \\
\text { yang paling berpengaruh dalam } \\
\text { membentuk perilaku remaja laki-laki } \\
\text { untuk merokok. Sementara iklan rokok } \\
\text { adalah faktor yang paling sedikit } \\
\text { mempengaruhi remaja untuk merokok. } \\
\text { Norma subyektif yang terbentuk dari }\end{array}$ \\
\hline
\end{tabular}




\begin{tabular}{|c|c|c|c|}
\hline & & & $\begin{array}{l}\text { teman sebaya mereka adalah merokok } \\
\text { merupakan identitas remaja ketika } \\
\text { bercengkrama dengan teman bermainnya. } \\
\text { Bercengkrama tanpa rokok adalah hal } \\
\text { yang tabu buat remaja, sehingga } \\
\text { dorongan merokok berasal dari teman } \\
\text { sebaya, bukan dari dorongan internal, diri } \\
\text { sendiri. Penelitian ini juga mendapatkan } \\
\text { bahwa uang untuk membeli rokok } \\
\text { didapatkan dari hasil bekerja. }\end{array}$ \\
\hline 4 & $\begin{array}{lr}\text { (Attaqy, } & \text { Fithria, \& } \\
\text { Hartaty, } & 2021 \text { ) } \\
\text { Hubungan } & \text { Pola } \\
\text { Komunikasi } & \text { Keluarga } \\
\text { Dengan } & \text { Perilaku } \\
\text { Merokok Pada Remaja }\end{array}$ & JIM FKep & $\begin{array}{l}\text { Berdasarkan hasil peneltian maka dapat } \\
\text { disimpulkan bahwa ada hubungan pola } \\
\text { komunikasi keluarga dengan perilaku } \\
\text { merokok pada remaja SMA Negeri } 9 \\
\text { Banda Aceh. Hal ini menyebabkan pihak } \\
\text { sekolah perlu melakukan bimbingan } \\
\text { konseling terkait perilaku merokok pada } \\
\text { usia remaja. }\end{array}$ \\
\hline 5 & $\begin{array}{l}\text { (Julaecha } \quad \& \\
\text { Wuryandari, 2021) } \\
\text { Pengetahuan dan Sikap } \\
\text { tentang Perilaku } \\
\text { Merokok pada }\end{array}$ & $\begin{array}{l}\text { Jurnal } \\
\text { Akademka } \\
\text { Baiturrahim } \\
\text { Jambi (JABJ) }\end{array}$ & $\begin{array}{l}\text { Pengetahuan dan sikap remaja terhadap } \\
\text { perilaku merokok menunjukkan } \\
\text { pengetahuan responden sebagian besar } \\
\text { baik serta memiliki sikap positif dan } \\
\text { sebagian besar responden tidak merokok. } \\
\text { Berdasarkan hasil uji statistik antara } \\
\text { pengetahuan dengan perilaku merokok } \\
\text { tidak terdapat hubungan bermakna } \\
\text { dengan nilai p value }>0,005 \text { dan hasil uji } \\
\text { statistik antara sikap dengan perilaku } \\
\text { merokok terdapat hubungan bermakna } \\
\text { dengan nilai p value }<0,005 \text {. }\end{array}$ \\
\hline 6 & $\begin{array}{lr}\text { Riyadi \& } & \text { Handayani, } \\
2021) & \text { Determinan } \\
\text { Perilaku } & \text { Merokok } \\
\text { Remaja di Kulon } & \text { Krogo Yogyakarta }\end{array}$ & $\begin{array}{l}\text { Journal } \\
\text { Holistic } \\
\text { Nursing } \\
\text { Science }\end{array}$ & $\begin{array}{l}\text { Terdapat pengaruh secara langsung dan } \\
\text { bersifat negative antara niat dan persepsi } \\
\text { kendali perilaku untuk tidak merokok } \\
\text { terhadap perilaku merokok remaja. Ada } \\
\text { pengaruh secara tidak langsung antara } \\
\text { pengetahuan, sikap dan persepsi perilaku } \\
\text { terhadap perilaku merokok remaja di } \\
\text { Kulon Progo Yogyakarta. }\end{array}$ \\
\hline 7 & 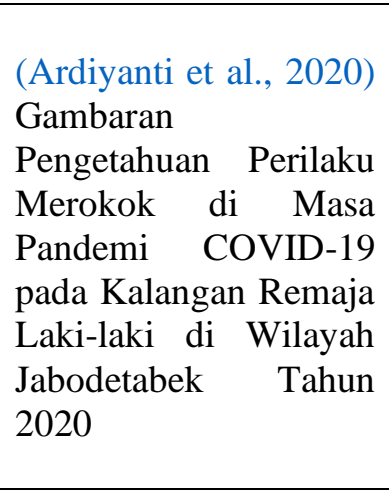 & $\begin{array}{l}\text { Jurnal Ilmu } \\
\text { Kesehatan } \\
\text { Indonesia } \\
\text { (JIKSI) }\end{array}$ & $\begin{array}{l}\text { Mayoritas responden dalam penelitian ini } \\
\text { merokok pada usia11-19 tahun. } \\
\text { Responden yang merokok masuk ke } \\
\text { dalam kategori ringan dan lebih memilih } \\
\text { merokok di dalam rumah. Kebanyakan } \\
\text { responden dalam penelitian ini sudah } \\
\text { merokok lebih dari satu tahun } \\
\text { dikarenakan stress atau emosional yang } \\
\text { tinggi. Di sisi lain perokok yang telah } \\
\text { aktif merokok mempunyai keinginan } \\
\text { untuk berhenti merokok. }\end{array}$ \\
\hline 8 & $\begin{array}{lr}\text { (Destri, } & \text { Sari, } \quad \& \\
\text { Perdana, } & 2019) \\
\text { Perilaku } & \text { Merokok dan }\end{array}$ & $\begin{array}{ll}\text { Jurnal } & \\
\text { Kesehatan } & \\
\text { Metro } \quad \text { Sai }\end{array}$ & $\begin{array}{l}\text { Terpengaruh teman sebaya, keterpaparan } \\
\text { iklan rokok, lingkungan keluarga, } \\
\text { terpengaruh guru dan uang jajan }\end{array}$ \\
\hline
\end{tabular}




\begin{tabular}{|c|c|c|c|}
\hline & $\begin{array}{ll}\text { Faktor } & \text { yang } \\
\text { Berhubungan } & \text { pada } \\
\text { Siswa } & \end{array}$ & Wawai & $\begin{array}{l}\text { meningkatkan kejadian perilaku } \\
\text { merokok. Perlu upaya mencegah perilaku } \\
\text { merokok dengan memberikan } \\
\text { keteladanan kepada siswa dari teman } \\
\text { sebaya keluarga, guru maupun } \\
\text { pengaturan iklan rokok oleh pemerintah. }\end{array}$ \\
\hline 9 & $\begin{array}{lr}\text { (Luji \& Lubis, 2019) } \\
\text { Hubungan } & \text { Perilaku } \\
\text { Merokok } & \text { Dengan } \\
\text { Persepsi } & \text { Remaja } \\
\text { Perokok } & \text { Tentang } \\
\text { Harga Diri } & \\
\end{array}$ & $\begin{array}{l}\text { Jurnal } \\
\text { Kesehatan } \\
\text { Madani } \\
\text { Medika }\end{array}$ & $\begin{array}{l}\text { Hasil uji Chi-square sebesar } 7,457 \\
\text { dengan nilai signifikan } 0,024(\alpha<0,05) \text {. } \\
\text { Hasil ini menunjukan terdapat hubungan } \\
\text { antara perilaku merokok dengan persepsi } \\
\text { remaja perokok tentang harga diri di } \\
\text { SMK Piri } 1 \text { Yogyakarta. }\end{array}$ \\
\hline 10 & $\begin{array}{l}\text { (Mirnawati, } \\
\text { Nurfitriani, Zulfiarini, } \\
\text { \& Cahyati, 2018) } \\
\text { Perilaku Merokok pada } \\
\text { Remaja Umur 13-14 } \\
\text { Tahun }\end{array}$ & $\begin{array}{l}\text { HIGEIA } \\
\text { Journal Of } \\
\text { Public Health } \\
\text { Research And } \\
\text { Development }\end{array}$ & $\begin{array}{l}\text { faktor yang mempengaruhi remaja } \\
\text { merokok diantaranya } \\
\text { jenis kelamin, teman sebaya, lingkungan } \\
\text { sekitar dan hasrat ingin mencoba. }\end{array}$ \\
\hline
\end{tabular}

\section{Hasil Dan Pembahasan}

Berdasarkan hasil pencarian literatur didapatkan faktor risiko yang dapat mempengaruhi perilaku merokok pada usai remaja yakni sebagai berikut:

1. Pengetahuan tentang rokok

Menurut (Bukit, 2019) pada penelitiannya menyebutkan bahwa terdapat hubungan bermakna antara pengetahuan remaja terhadap perilaku merokok $\mathrm{p}$ $(0,000)<\alpha(0,05)$. Rata-rata semua siswa berpengetahuan baik tentang rokok. Penelitian ini sejalan dengan penelitian (Alamsyah \& Nopianto, 2017) menunjukkan bahwa ada hubungan antara pengetahuan terhadap perilaku merokok. Selain itu, penelitian ini juga sejalan dengan penelitian yang dilakukan oleh Julaecha dan (Julaecha \& Wuryandari, 2021) mengemukakan bahwa mayoritas responden memiliki pengetahuan baik tentang bahaya merokok sebanyak 28 orang $(57,1 \%)$ hal ini karena banyaknya dan mudahnya informasi tentang bahaya merokok diperoleh oleh remaja seperti iklan tentang bahaya merokok, informasi yang ada di media cetak maupun elektronik menyebabkan responden memiliki pengetahuan yang baik, selain itu pengetahuan responden juga di dapatkan dari orang tua yang melarang anaknya merokok dengan alasan yang bermacam- macam, pemahaman yang diberikan orang tua ini mempengaruhi pengetahuan responden.

Namun, terdapat hasil penelitian lain yang mengatakan bahwa masih terdapat responden yang memiliki pengetahuan baik namun tetap merokok sebanyak 10 orang $(35,7 \%)$ dan berdasarkan hasil uji statitik tidak terdapat hubungan bermakna antara pengetahuan dengan perilaku merokok menurut asumsi peneliti hal ini dimungkinkan karena faktor lingkungan, teman yang dapat mempengaruhi perilaku merokok pada remaja, dan remaja sudah memulai merokok pada usia remaja awal dimana kondisi psikisnya masih labil. Hasil penelitian ini sejalan dengan penelitian Dian P (2019) tentang tingkat pengetahuan dan sikap tentang perilaku merokok pada 
remaja di SMKN 3 Ambon menyatakan bahwa tidak terdapat hubungan antara pengetahuan dengan perilaku merokok pada remaja dan didukung oleh penelitian (Rachmat, Thaha, \& Syafar, 2013) tentang perilaku merokok remaja Sekolah Menengah Pertama menyatakan bahwa tidak terdapat hubungan antara pengetahuan dengan perilaku merokok.

2. Peran orang tua

Berdasarkan hasil penelitian yang dilakukan oleh (Attaqy et al., 2021) menyatakan bahwa sebagian besar responden mengalami pola komunikasi fungsional yaitu sebanyak $88(56,4 \%)$ responden dan yang mengalmi pola komunikasi disfungsional sebanyak $68(43,6 \%)$ responden. Kategori remaja dengan pola komunikasi keluarga fungsional dalam penelitian ini ratarata menunjukkan bahwa terdapat ketegasan dan kejelasan anggota keluarga dalam menyatakan kebutuhan dan perasaannya, mendapatkan dan merespon umpan balik secara baik, menunjukkan perhatian, frekuensi penyampaian pesan emosional yang baik, pola pengiriman pesan penting sering dilakukan dan kesesuaian pesan dengan perkembangan anggota keluarga mengenai isi dan intruksi pesan yang disampaikan.

Selanjutnya dari 68 responden dengan pola komunikasi disfungsional terdapat 63 responden diantaranya yang berperilaku merokok yaitu 5 responden perokok ringan dan 58 responden perokok berat $(92,65 \%)$ dengan demikian menunjukkan bahwa responden dengan pola komunikasi disfungsional 92,65\% kemungkinan berperilaku merokok. Masa remaja dipengaruhi oleh banyak faktor yaitu terutama faktor keluarga. Keluarga memilik peranan besar dalam memberikan pengaruh pada anak, karena kedudukannya yang primer dan fundamental. Walaupun dalam masyarakat keluarga sering dianggap suatu kesatuan yang kecil, akan tetapi pengaruhnya bagi anak sangat besar, terutama bagi anak dalam menghadapi tahap awal dan tahap kritis anak Orang tua sebagai orang pertama dalam keluarga dalam berinteraksi dengan remaja memiliki peranan penting dalam pembentukan dan perkembangan mental anak dalam mengatasi berbagai kesulitan-kesulitan yang dihadapi remaja, mencakup didalamnya pemberian kasih sayang, penerimaan, pemenuhan kebutuhan anak, aturan-aturan, disiplin serta membangun kepercayaan diri, dalam menampilkan peran yang baik dan menciptakan lingkungan yang menarik yang dapat diwujudkan dengan komunikasi (Alif \& Harahap, 2013).

3. Peran teman sebaya

Sesuai dengan penelitian yang dilaukan oleh (Rezeki \& Utari, 2021) menyatakan bahwa terdapat perbedaan proporsi merokok pada teman sebaya yang berperan dan yang tidak berperan $(p<0,05)$. Terlihat yang merokok lebih banyak pada teman sebaya yang berperan sebanyak $58,2 \%$ dibanding dengan teman sebaya yang tidak berperan sebanyak $13,2 \%$. Dilihat dari nilai OR teman sebaya yang berperan berisiko 9,1 kali berperilaku merokok dibanding teman sebaya yang tidak berperan. Hal ini sejalan dengan penelitian yang dilakukan (Astuti, 2018) yang menyatakan bahwa ketika kumpul-kumpul (nongkrong) di tempat berkumpulnya anakanak sekolah tersebut. Tidak ada informan yang mengatakan merokok atas 
inisiatif sendiri. Seluruhnya menerangkan memulai kebiasaan merokok dari dorongan, paksaan, atau rayuan teman-teman.

4. Pengaruh iklan

Berdasarkan penelitian yang dilakukan oleh (Destri, Sari, \& Perdana, 2019) dari 36 responden dengan perilaku merokok berat, ada iklan tentang rokok terdapat 26 responden $(72.2 \%)$, dan tidak ada iklan tentang rokok terdapat 10 responden $27.8 \%$ ). Dari 35 responden dengan perilaku merokok ringan, ada iklan tentang rokok terdapat 14 responden $(40.0 \%)$, dan tidak ada iklan tentang rokok terdapat 21 responden $(60 \%)$. Setelah dilakukan uji statistik dengan menggunakan uji chisquare dengan tingkat kepercayaan 95\% diperoleh nilai p-value 0.013 yang berarti lebih kecil dari $\alpha$-value $(0,05)$. Dengan demikian dapat dinyatakan bahwa ada hubungan antara iklan dengan perilaku merokok pada siswa di Sekolah Menengah Atas Negeri 2 Kabupaten Garut Tahun 2018. Melihat iklan di media massa dan elektronik yang menampilkan gambaran bahwa perokok adalah lambang kejantanan atau glamour membuat seseorang seringkali terpicu untuk mengikuti perilaku yang ada di iklan tersebut.

Menurut Vakratsas dalam (Liliweri, 2017) iklan merupakan informasi yang dibentuk dari olahan pikiran manusia dan mempengaruhi perasaan individu sehingga menjadi penyebab penggunaan dari suatu produk. Iklan merupakan bentuk kegiatan komunikasi non personal yang disampaikan lewat media dengan membayar ruang yang dipakainya untuk menyampaikan pesan dan bersifat membujuk (persuasif) kepada konsumen oleh perusahaan, lembaga non komersial, maupun pribadi yang berkepentingan.

5. Uang saku

Berdasarkan penelitian sebelumnya menyatakan bahwa informan membeli rokok tidak hanya mendapat uang saku dari orang tua, informan tersebut juga memperoleh dari bekerja seperti mengamen, jasa parker, ojek payung dan lain-lain. Ada pula informan yang mendapatkan rokok dari pemberian teman. Jika sedang tidak memiliki uang, maka informan akan meminta rokok pada teman yang memiliki rokok. Tidak jarang juga ada kondisi tidak memiliki uang untuk membeli rokok dan tidak ada yang dapat diminta, maka mereka memilih tidak merokok. Sebagian remaja merokok mengatakan selalu memiliki uang jika ingin merokok.

6. Rasa ingin tahu tentang rokok (coba-coba)

Sesuai dengan penelitian yang telah dilakukan sebelumnya, Bila melihat umur pertama kali merokok dari $14(47 \%)$ responden yang pernah merokok, sebanyak 2 (7\%) remaja laki-laki yang sudah mulai merokok sejak SD umur 10 tahun, sebanyak 8 (27\%) remaja laki-laki mulai merokok sejak SMP umur 13-14 tahun, dan sebanyak 1 (3\%) orang remaja mulai merokok sejak SMA umur 16 tahun. Selain itu perilaku merokok banyak terjadi dimulai pada masa remaja, semakin muda umur mulai merokok semakin kuat kebiasaan merokok dan semakin sulit untuk berhenti merokok. 


\section{Kesimpulan}

Merokok merupakan salah satu pemicu timbulnya berbagai macam penyakit menular, tidak menular hingga penyakit yang dapat menyebabkan kematian. Terdapat beberapa faktor pemicu atau penyebab timbulnya perilaku merokok pada usia remaja yakni kurangnya pengetahuan atau pemahaman tentang rokok, bahaya rokok, kerugian dalam mengonsumsi rokok, kemudian kurangnya peran serta keluarga dalam mengontrol kegiatan anak sehingga munculnya rasa ingin tau atau coba-coba untuk mengonsumsi rokok, mendapat pengaruh teman sebaya baik saat kumpul atau saat sedang bermain, kemudian pengaruh iklan yang ditayangkan di sosial media, televisi maupun media lainnya, uang saku yang diberikan oleh orang tua cukup untuk membeli rokok. Sehingga, sangat diperlukan sosialisasi terkait bahaya merokok pada kalangan remaja sehingga terhindar dari berbagai macam faktor pemicu timbulnya rasa ingin tahu untuk mengonsumsi rokok. 


\section{BIBLIOGRAFI}

Alamsyah, Agus, \& Nopianto, Nopianto. (2017). Determinan perilaku merokok pada remaja. Jurnal Endurance: Kajian Ilmiah Problema Kesehatan, 2(1), 25-30. Google Scholar

Alif, Gunawan, \& Harahap, Y. (2013). Komunikasi inter-personal dan fasilitas kesehatan: Pengaruhnya terhadap kepercayaan, loyalitas dan wom rumah sakit. Journal of Business and Entrepreneurship, 1(3), 1-12. Google Scholar

Ardiyanti, Putri Dwi, Harzani, Septia, Rahmah, Syifa Aulia, Putri, Zalfa Maharani, Putri, Zalma Nur Khadijah, \& Mustakim, Mustakim. (2020). Gambaran Pengetahuan Perilaku Merokok di Masa Pandemi COVID-19 pada Kalangan Remaja Laki-Laki di Wilayah Jabodetabek Tahun 2020. Jurnal Ilmu Kesehatan Indonesia (JIKSI), 1(2). Google Scholar

Astuti, Nurul Huriah. (2018). Perilaku Merokok Remaja Laki-laki siswa SMP swasta di Depok. Arkesmas (Arsip Kesehatan Masyarakat), 3(2), 83-94. Google Scholar

Attaqy, Cut Fella, Fithria, Fithria, \& Hartaty, Neti. (2021). Hubungan Pola Komunikasi Keluarga Dengan Perilaku Merokok Pada Remaja. Jurnal Ilmiah Mahasiswa Fakultas Keperawatan, 5(2). Google Scholar

Bukit, Rosmeri Br. (2019). Faktor Penyebab Perilaku Merokok Di Smk Akbar Kota Pekanbaru. Ensiklopedia of Journal, 1(4). Google Scholar

Destri, Yuhelva, Sari, Fitri Eka, \& Perdana, Agung Aji. (2019). Perilaku Merokok dan Faktor yang Berhubungan pada Siswa. Jurnal Kesehatan Metro Sai Wawai, 12(2), 17-26. Google Scholar

Julaecha, Julaecha, \& Wuryandari, Ajeng Galuh. (2021). Pengetahuan dan Sikap tentang Perilaku Merokok pada Remaja. Jurnal Akademika Baiturrahim Jambi, 10(2), 313-318. Google Scholar

Larasati, Aprilia. (2016). Perbedaan derajat keasaman (ph) saliva pada perokok kretek dan non kretek. UIN Syarif Hidayatullah Jakarta: Fakultas Kedokteran dan Ilmu Kesehatan, 2016. Google Scholar

Liliweri, Alo. (2017). Komunikasi antar personal. Prenada Media. Google Scholar

Luji, Lukas, \& Lubis, Dina Putri Utami. (2019). Hubungan Perilaku Merokok Dengan Persepsi Remaja Perokok Tentang Harga Diri. Google Scholar

Mirnawati, Mirnawati, Nurfitriani, Nurfitriani, Zulfiarini, Febriana Maya, \& Cahyati, Widya Hary. (2018). Perilaku merokok pada remaja umur 13-14 tahun. HIGEIA (Journal of Public Health Research and Development), 2(3), 396-405. Google Scholar 
Rachmat, Muhammad, Thaha, Ridwan Mochtar, \& Syafar, Muhammad. (2013). Perilaku merokok remaja sekolah menengah pertama. Kesmas: Jurnal Kesehatan Masyarakat Nasional (National Public Health Journal), 7(11), 502-508. Google Scholar

Rezeki, Sahbainur, \& Utari, Diah Mulyati. (2021). Faktor-Faktor yang Mempengaruhi Perilaku Merokok Pada Anak Sekolah Dasar di SD Pinggiran Banda AcehTahun 2021. Journal Of Healthcare Technology And Medicine, 7(1), 476-487. Google Scholar

Riyadi, Sujono, \& Handayani, Sri. (2021). Determinan Perilaku Merokok Remaja di Kulon Progo Yogyakarta. Journal of Holistic Nursing Science, 8(1), 9-18. Google Scholar

\section{Copyright holder:}

Uswatun Hasanah, Zahratul Hayati (2022)

First publication right:

Syntax Literate: Jurnal Ilmiah Indonesia

This article is licensed under:

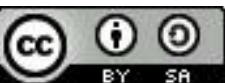

